\title{
Wash hand education and hand sanitizer preparation workshop to the community in order to prevent COVID-19 transmission
}

\author{
Lia Laila $^{1 *}$, Marianne ${ }^{2}, \mathrm{~T}$. Ismanelly Hanum ${ }^{1}$, Hetty Lendora Maha ${ }^{1}$ \\ ${ }^{1}$ Departemen Teknologi Farmasi, Fakultas Farmasi, Universitas Sumatera Utara \\ ${ }^{2}$ Departemen Farmakologi, Fakultas Farmasi, Universitas Sumatera Utara \\ *Email: lialaila@usu.ac.id
}

\begin{abstract}
Communicable disease, COVID-19 easily spreads through the respiratory droplets. Therefore, WHO recommends the physical distancing policy to prevent the transmission. However, the transmission of SARSCoV2 virus causing COVID-19 occurred not only by human interaction, but also the things that had been touched by the people suffered COVID-19 have potential as the media for the virus transmission. Then, it is necessary to anticipate the worries in the form of correct wash hand application or using hand sanitizer. The activities that had been done were giving an education about the communicable disease, COVID-19, how it is spread and how to prevent it; performing correct hand wash and preparation of alcohol based hand sanitizer in the form of gel to the society of Belawan I neighborhoods, Medan Belawan District, Medan City. The survey analysis results showed that the community service that had been conducted in Belawan I neighborhoods gave benefits and elevated approximately $49.5 \%$ the knowledge of the community regarding the COVID-19 and hand sanitizer preparation.
\end{abstract}

Keyword: COVID-19, hand wash, virus, hand sanitizer

\begin{abstract}
Abstrak
Penyakit menular COVID-19 sangat mudah menyebar melalui media droplet pernafasan sehingga WHO menyarankan pemberlakuan physical distancing untuk mencegah penyebarannya. Akan tetapi penularan virus SARS-CoV2 penyebab COVID-19 tidak hanya dapat terjadi jika ada interaksi antar manusia, ternyata bendabenda mati yang pernah tersentuh penderita COVID-19 juga berpotensi sebagai media penyebaran virus tersebut. Sehingga perlu antisipasi dalam bentuk penerapan cuci tangan yang benar ataupun penggunaan hand sanitizer. Bentuk kegiatan yang dilakukan adalah dengan memberikan penyuluhan terkait penyakit menular khususnya COVID-19, bagaimana penularan dan pencegahannya, praktek cara cuci tangan yang benar dan demo pembuatan hand sanitizer berbasis alkohol dalam bentuk sediaan gel kepada masyarakat Kelurahan Belawan I, Kecamatan Medan Belawan Kota Medan. Dari hasil analisa angket maka kegiatan pengabdian yang dilaksanakan di Kelurahan Belawan I memberikan manfaat dan meningkatkan rata-rata 49,5\% pengetahuan masyarakat setempat terkait penyakit COVID-19 dan pembuatan hand sanitizer.
\end{abstract}

Kata kunci: COVID-19, cuci tangan, virus, hand sanitizer.

\section{PENDAHULUAN}

Penyakit COVID-19 saat ini telah menginfeksi hampir seluruh dunia dengan penyebarannya yang begitu masif. Penyakit ini mulai terdeteksi pertama kali di Wuhan, China pada akhir tahun 2019 dan mulai menyebar ke seluruh dunia hingga ke Indonesia yang diketahui pada awal Maret 2020. Dari data World Health Organization tanggal 29 April 2020 jumlah kasus di seluruh dunia yang telah dilaporkan adalah sebanyak 3.024.059 kasus dengan angka kematian mencapai 208.112 jiwa (WHO, 2020). Hal ini memberikan tingkat mortalitas penyakit ini rata-rata sebesar $6,88 \%$. Di Indonesia sendiri, jumlah kasus positif yang dilaporkan sebanyak 9.771 dengan angka kematian mencapai 784 jiwa dan memberikan tingkat mortalitas sebesar 8,02\%. Menurut Tim Media Center Gugus Covid-19 Sumatera Utara (2020) per tanggal 29 April 2020, jumlah 
kasus positif adalah 114 orang, pasien dalam pemantauan (PDP) sebanyak 140 orang dengan pasien meninggal sebanyak 12 orang dan yang sembuh 41 orang.

Virus SARS-CoV2 ini dapat menyebar dari manusia ke manusia melalui droplet pernafasan seperti batuk dan bersin. Masa inkubasi virus ini diperkirakan rata-rata 5,2 hari. Gejala yang ditimbulkan juga bervariasi, mulai dari batuk, demam, pegal-pegal, sakit kepala, sesak nafas, diare, tenggorokan kering, dan pneumonia (Rothan and Byrareddy, 2020). Sekitar 1\% kasus melaporkan bahwa pasien menderita COVID-19 tanpa adanya gejala, dan ini lebih membahayakan karena memiliki potensi untuk menularkan lebih besar (Wu et.al, 2020).

Walaupun secara umum penularan virus ini melalui droplet pernafasan, tetapi kemungkinan virus tersebut berada di benda-benda yang telah dipegang penderita COVID-19 juga merupakan salah satu media penyebaran. Hal lain yang dapat dilakukan sebagai upaya pencegahan adalah dengan mencuci tangan atau menggunakan hand sanitizer. Seperti jenis virus corona yang lain, SARS-CoV2 sangat sensitif terhadap sinar ultraviolet dan panas, juga virus ini dapat diinaktifkan dengan pelarut lemak seperti eter (75\%), etanol, desinfektan yang mengandung klorin, asam peroksiasetat dan kloroform kecuali klorheksidin (Cascella et al, 2020). Sehingga senyawasenyawa ini dapat digunakan sebagai bahan untuk pembuatan desinfektan termasuk hand sanitizer.

Namun ketersediaan produk hand sanitizer di pasaran sekarang semakin langka dan harganya juga menjadi mahal. Untuk itu perlu dilakukan pelatihan bagi masyarakat agar dapat membuat hand sanitizer secara mandiri sebagai upaya pencegahan penyakit menular melalui tangan. Di samping penggunaan hand sanitizer, melakukan cuci tangan yang benar dengan sabun adalah cara yang paling efektif untuk menghilangkan bakteri dan virus penyebab penyakit menular seperti COVID-19 (Dirjen. Pencegahan dan Pengendalian Penyakit-Kemenkes RI, 2020). Sehingga diperlukan edukasi bagaimana melakukan cuci tangan yang benar menggunakan sabun.

\section{METODE PELAKSANAAN}

Kegiatan pengabdian dilakukan menggunakan 2 metode pendekatan meliputi penyuluhan dan pelatihan.

a. Tahap I (Penyuluhan)

Pada tahap awal masyarakat diberikan edukasi tentang bahaya penyakit menular COVID-19, apa saja bentuk pencegahannya termasuk melakukan cuci tangan yang benar sebagai salah satu upaya mencegah penularan COVID-19. Penyuluhan dilaksanakan dengan metode ceramah, demo dan diskusi. Peserta juga diajak untuk mempraktekkan gerakan mencuci tangan menggunakan sabun yang benar.

b. Tahap II (Pelatihan Pembuatan Hand Sanitizer)

Pada tahap ini masyarakat dilatih untuk membuat produk hand sanitizer. Pelatihan ini dilakukan dalam bentuk demo video cara pembuatan hand sanitizer, mulai dari persiapan alat dan bahan yang diperlukan sampai bagaimana teknis pembuatan sampai pengemasannya ke dalam wadah. Masyarakat juga akan diberikan alat untuk membuat hand sanitizer secara mandiri.

Untuk meningkatkan pengetahuan masyarakat maka diberikan juga edukasi dalam bentuk buku saku dan modul. Buku saku merupakan kumpulan informasi terkait penyakit COVID-19 dan modul merupakan teknis penggunaan dan pembuatan hand sanitizer. Formula hand sanitizer yang digunakan merupakan modifikasi dari formula hand sanitizer Organisasi Kesehatan Dunia (WHO) yang dibuat dalam bentuk gel.

Pengukuran keberhasilan kegiatan dilakukan dengan menggunakan angket penilaian kegiatan dan juga angket pre-test dan post-test untuk mengukur tingkat pengetahuan masyarakat terkait topik pengabdian.

\section{HASIL DAN PEMBAHASAN}

Kegiatan penyuluhan dan demo praktek pembuatan hand sanitizer dilaksanakan dengan lancer dan tanpa kendala di aula pertemuan kelurahan Belawan I, Kec. Medan Belawan. Peserta yang hadir 
dilengkapi dengan masker serta hand sanitizer dan diberikan jarak pada kursi untuk mematuhi protokol kesehatan seperti yang terlihat pada Gambar 3.1.

Kegiatan diawali dengan pemaparan edukasi tentang bahaya penyakit menular COVID-19 sekaligus praktek mencuci tangan yang benar dengan menggunakan sabun yang telah diberikan pewarna. Peserta diminta mengikuti gerakan mencuci tangan yang benar sehingga seluruh bagian tangan berwarna yang menandakan bahwa tangan telah benar-benar terpapar oleh sabun secara keseluruhan seperti yang terlihat pada Gambar 3.2.

Kegiatan dilanjutkan dengan menampilkan video demo cara pembuatan hand sanitizer, dimana tahapan pembuatan hand sanitizer ini juga dijelaskan pada buku modul yang diberikan kepada peserta untuk meningkatkan pemahaman.

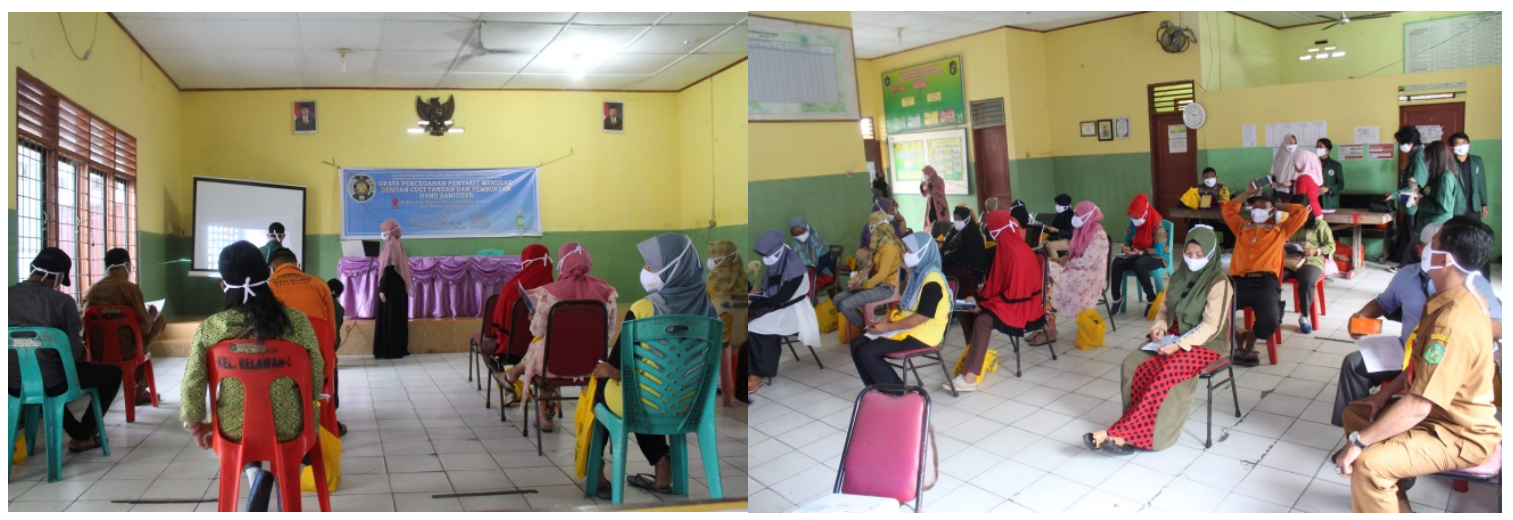

Gambar 3.1. Peserta pengabdian masyarakat menggunakan masker dan menjaga jarak untuk mematuhi protokol kesehatan

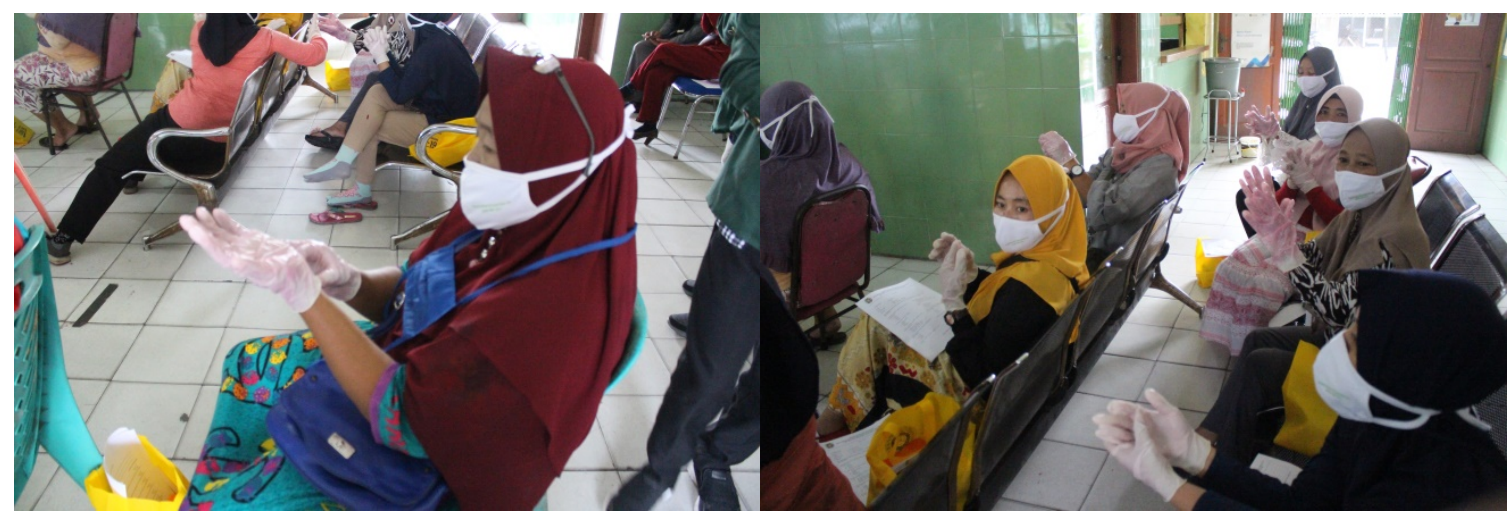

Gambar 3.2 Peserta melakukan praktek gerakan mencuci tangan dengan benar menggunakan sabun berwarna

Hasil analisis angket terkait kegiatan pengabdian kepada masyarakat yang dilakukan dapat dilihat pada gambar 3.3.

Dari gambar 3.3 dapat dilihat dari masing-masing pertanyaan memberikan persentase yang berbeda. Untuk pertanyaan nomor 1 yaitu tentang kemudahan penerimaan materi yang disampaikan penyuluh maka seluruh peserta (100\%) menyatakan mudah. Hal ini menunjukkan bahwa, penyuluh telah menyampaikan materi dengan baik sehingga mudah dipahami oleh peserta. 


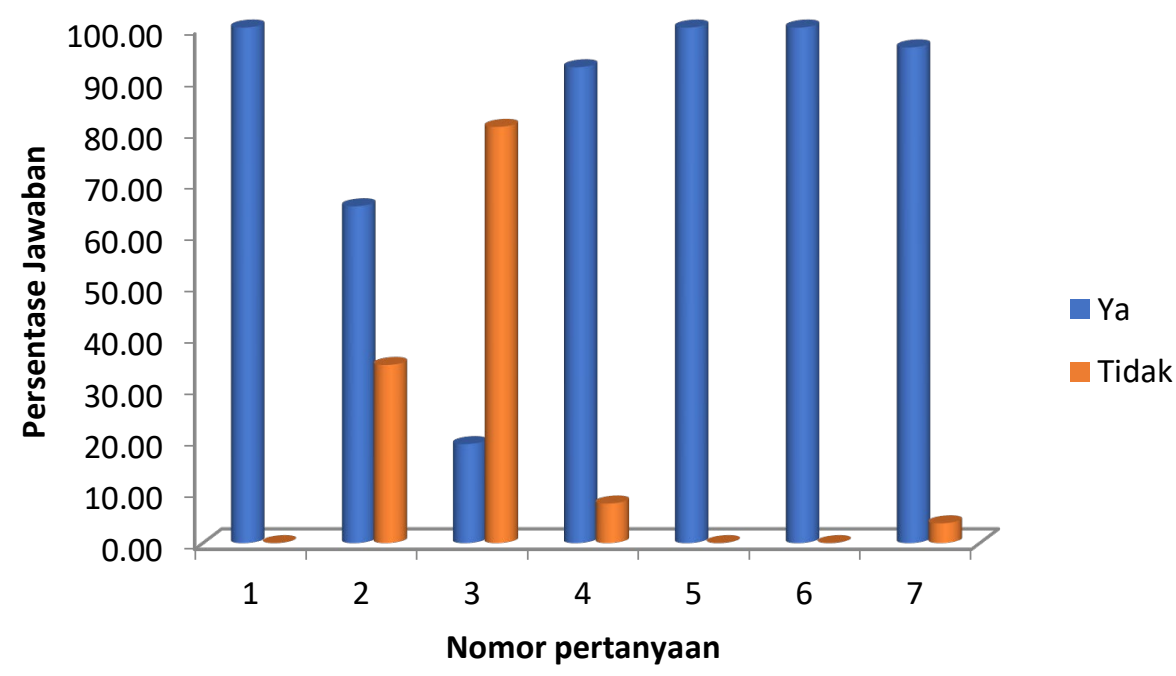

Gambar 3.3. Persentase hasil jawaban peserta terkait angket penilaian kegiatan pengabdian kepada masyarakat.

Untuk pertanyaan nomor 2 yang menanyakan tentang cara pencegahan COVID-19 menunjukkan bahwa 34,62 \% dari peserta yang hadir belum mengetahui cara-cara pencegahan COVID-19. Oleh karena itu, kegiatan penyuluhan yang dilakukan telah sesuai dengan kebutuhan masyarakat, khususnya kepada para peserta untuk meningkatkan pengetahuan peserta terkait pencegahan COVID19.

Untuk pertanyaan 3 yaitu tentang cara pembuatan hand sanitizer, hasil analisa angket menunjukkan bahwa $80,77 \%$ dari jumlah peserta yang hadir belum mengetahui cara pembuatan hand sanitizer sehingga pemberian pelatihan pembuatan hand sanitizer yang dilakukan merupakan kegiatan yang tepat sasaran.

Untuk pertanyaan nomor 4 terkait kemudahan pembuatan hand sanitizer yang ditampilkan melaluui demo video mendapatkan respon $92,31 \%$ dari seluruh peserta menyatakan mudah untuk dibuat. Dengan ini menunjukkan bahwa, penyampaian pelatihan melalui video demo dapat dipahami oleh peserta.

Untuk pertanyaan nomor 5 tentang manfaat buku saku dan modul maka seluruh peserta (100\%) menyatakan bahwa buku saku dan modul yang disediakan oleh tim pengabdian bermanfaat bagi peserta.

Untuk pertanyaan nomor 6 tentang manfaat dari kegiatan pengabdian yang dilakukan maka seluruh peserta $(100 \%)$ menyatakan bermanfaat.

Untuk pertanyaan nomor 7 tentang kesediaan peserta untuk mengikuti kegiatan pengabdian di lain kesempatan maka 96,16\% dari peserta menyatakan bersedia. Bahkan peserta juga mengharapkan kegiatan-kegiatan serupa dilaksanakan kembali di daerah mereka dengan topic kegiatan yang berbeda.

Hasil analisis angket pengetahuan peserta terkait COVID-19 dan hand sanitizer dapat dilihat pada Gambar 3.4 dan Gambar 3.5. 


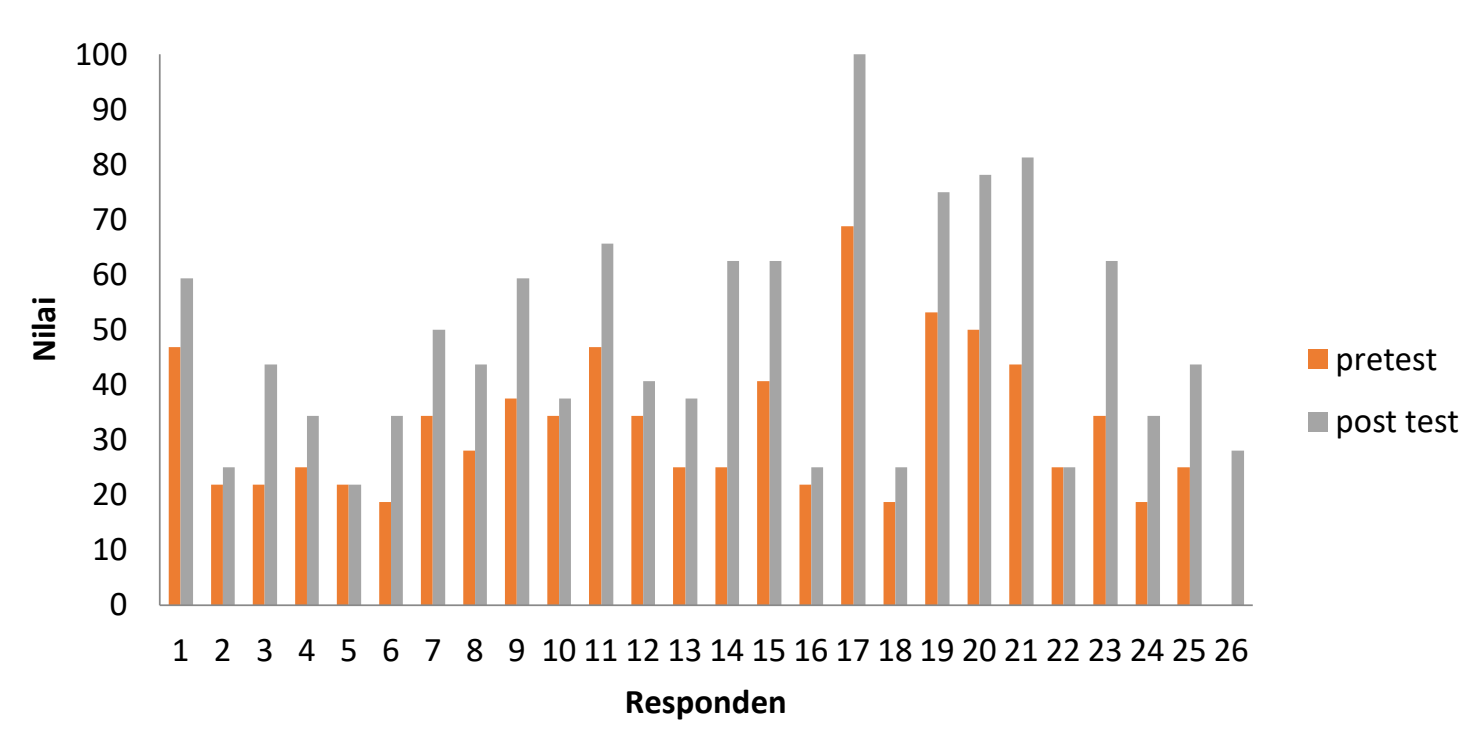

Gambar 3.4. Hasil analisis angket pretest dan post-test masyarakat terhadap pengetahuan mengenai COVID-19 dan hand sanitizer

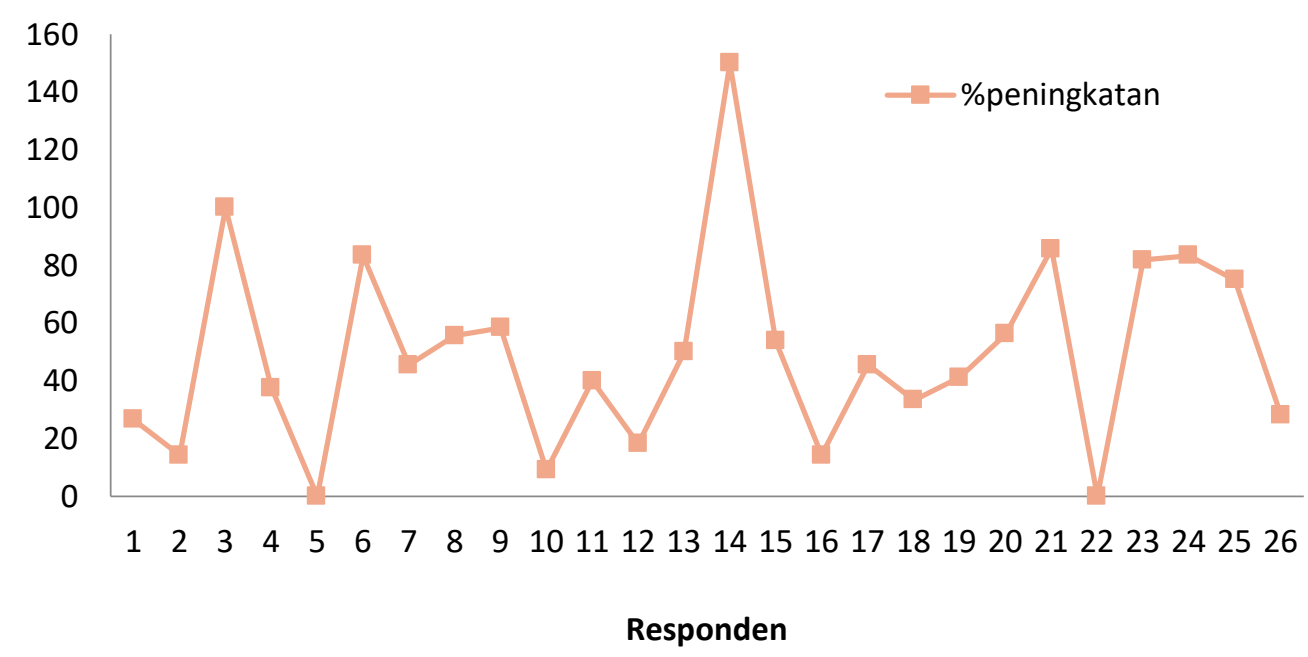

Gambar 3.5. Persentase peningkatan pengetahuan masyarakat terhadap penyakit COVID-19 dan hand sanitizer

Dari hasil analisis angket pada Gambar, terlihat bahwa hampir seluruh responden menunjukkan peningkatan pengetahuan. Peningkatan pengetahuan masyarakat rata-rata sebesar $49,5 \%$ setelah mengikuti penyuluhan dan pelatihan yang diberikan tim pengabdian. Hal ini menunjukkan bahwa kegiatan pengabdian yang dilakukan yaitu dengan metode penyuluhan dan pelatihan menggunakan demo video dapat menambah pengetahuan masyarakat terkait penyakit COVID-19 dan pencegahannya serta pengetahuan tentang penggunaan dan pembuatan hand sanitizer.

\section{KESIMPULAN}

Adapun kesimpulan dari kegiatan pengabdian yang telah dilaksanakan adalah sebagai berikut:

a. Kegiatan pengabdian kepada masyarakat terkait upaya pencegahan penyakit COVID-19 dengan cuci tangan dan pembuatan hand sanitizer telah memberikan manfaat kepada masyarakat. 
b. Peserta mendapatkan manfaat dari kegiatan pengabdian yang dilakukan berupa produk hand sanitizer, buku saku tentang COVID-19 dan modul pembuatan hand sanitizer.

c. Kegiatan pengabdian yang dilaksanakan meningkatkan $49,5 \%$ pengetahuan masyarakat terkait penyakit COVID-19 dan cara pembuatan hand sanitizer.

\section{UCAPAN TERIMAKASIH}

Penulis mengucapkan terima kasih kepada Lembaga Pengabdian kepada Masyarakat Universitas Sumatera Utara yang telah memberikan dana pengabdian melalui skim Mono Tahun Dosen Muda sesuai dengan surat perjanjian penugasan pelakasanaan nomor 291/UN5.2.3.2.1/PPM/2020, Tanggal 9 Juni 2020.

\section{DAFTAR PUSTAKA}

Cascella, M., Rajnik, M., Cuomo, A., et al. Features, Evaluation and Treatment Coronavirus. (COVID-19). Updated 6 Jan 2020. StatPearls [Internet], Treasure Island (FL): StatPearls Publishing. Jan 2020

Dirjen. Pencegahan dan Pengendalian Penyakit-Kemenkes RI, 2020, Pedoman Pencegahan Dan Pengendalian COVID-19. Kementerian Kesehatan RI. Diterbitkan 27 Maret 2020.

Pemprov Sumut. Sumut Tanggap Covid-19 diakses tanggal 30 April 2020. Tersedia di: http://covid19.sumutprov.go.id/

Rothan, H.A., \& Byrareddy, S.N. The Epidemiology and Pathogenesis of Coronavirus Disease (COVID-19) outbreak. Journal of Autoimmunity. Vol. 109. 2020.

Tim Gugus Tugas Percepatan Penanganan Covid-19 Pemerintah Kota medan. Data Per-Kelurahan Di Kecamatan Medan Belawan Terkait Covid-19 Kota Medan. Diakses tanggal 30 April 2020. Tersedia

https://covid19.pemkomedan.go.id/index.php?page=stat_kel\&kec=Medan\%20Belawan

WHO. 2020. Novel Coronavirus (COVID-19) situation Dashboard on 30 April 2020. Cited 30 April 2020. Available on: https://covid19.who.int/

Wu, D., Wu, T., Liu, Q. Yang, Z. 2020. The SARS-CoV-2 Outbreak: What we know. International Journal of Infectious Disease. Vol. 94: 44-48. 